\title{
Post-emergence herbicides are cost effective for vineyard floor management on the Central Coast
}

by Laura Tourte, Richard Smith, Larry Bettiga,
Tiffany Bensen, Jason Smith and Daryl Salm

Central Coast growers are under increasing scrutiny and regulatory pressure to manage herbicide use because of their farmland's proximity to the Monterey Bay and National Marine Sanctuary. Vineyard floor management practices typically consist of a combination of weed control strategies, including herbicide use and cover crops. We evaluated nine combinations of vineyard floor management practices for their impacts on fruit yield, quality and costs. We found that compared to the grower standard, post-emergence herbicide treatments generally used smaller amounts of chemicals and were less costly, with similar yields and quality.

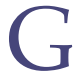
rowers along California's Central JCoast are under increasing pressure to keep herbicides from contaminating groundwater, and in turn, the Monterey Bay and National Marine Sanctuary. In vineyards, weed control generally consists of both pre- and post-emergence herbicide applications. The common pre-emergence herbicide simazine has been identified as a contamination risk for groundwater. This project was initiated to compare the long-term effects of floor management practices and alternative weed-control strategies on vineyard productivity over five growing seasons (2001 to 2005). In addition, we evaluated the associated economics over four growing seasons (2002 to 2005).

\section{Vineyard floor management}

Vineyard floors are managed to facilitate cultural practices and reduce competitive effects from noncrop vegetation. In California, key strategies for managing vineyard floors and successfully producing wine grapes are

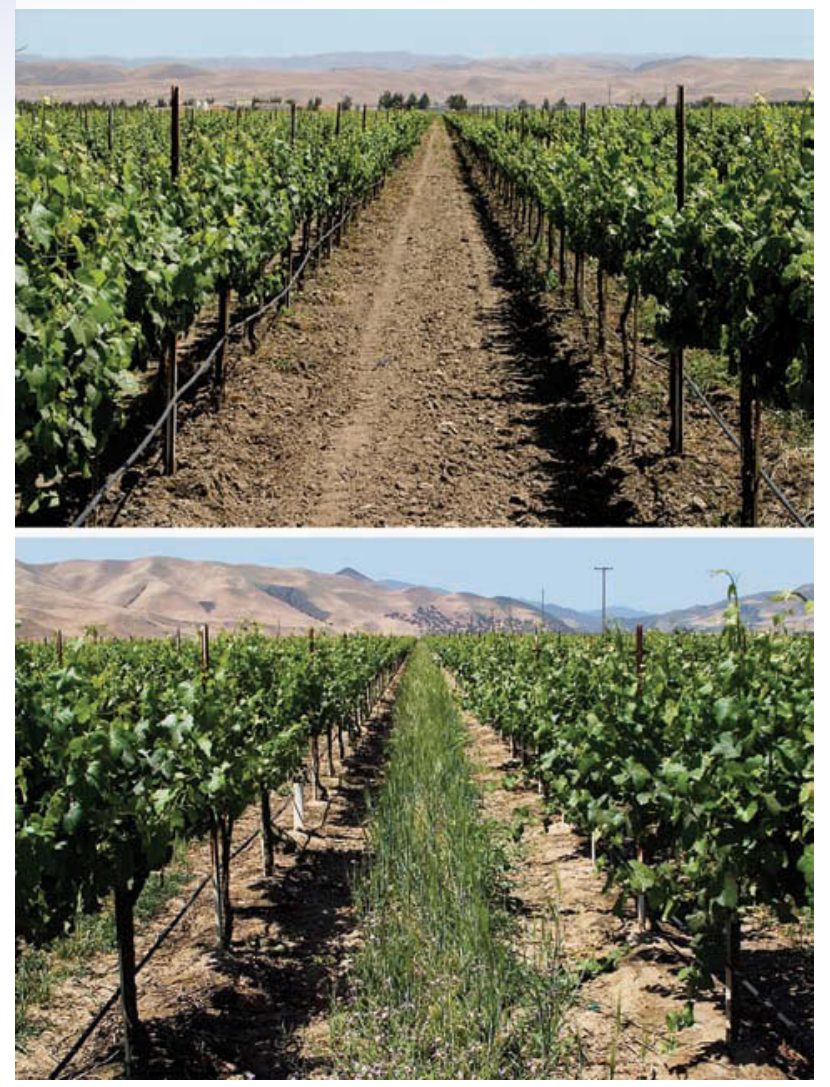

Vineyard floors are managed to prevent competition from vegetation that can inhibit grape yields and quality. Top, cultivated bare ground in the row middle; bottom, a cover crop.

herbicide use, mechanical weed control and cover-cropping (Elmore et al. 1997; Ingels et al. 1998). These practices, used alone or in combination, must be considered carefully because they have both direct and indirect costs as well as production implications for wine grapes. A grower's selection of vineyard floor management practices is based on numerous factors including production philosophy, terrain, soil type, irrigation system, economics, risk management, and environmental and regulatory pressures.

Weeds compete with grapevines for water, soil nutrients and sometimes sunlight. Weed competition is most severe during the first 3 years of vine establishment, when root growth is limited. However, dense weed populations can also reduce growth and yields in well-established vineyards (Hembree et al. 2006). In addition, vineyards with high weed populations may require additional water and fertilizer to maintain production (Lanini and Bendixen 1992).
Cover crops may be either planted, or resident, vegetation in vineyard row middles. In vineyards, cover crops: benefit vine growth and productivity (Costello and Daane 1997; Hirschfelt et al. 1993); reduce nutrient loss and cycle nitrogen for crop growth (Christensen 1971; Hirschfelt et al. 1993; Bettiga et al. 2006); and improve soil structure and prevent erosion (Gaffney and van der Grinten 1991; Bettiga et al. 2006). Because growers recognize the importance of cover crops for producing grapes, reducing erosion and improving water quality, more than $90 \%$ of Central Coast vineyards are cover-cropped. However, due to the low rainfall in this area, cover crops are typically planted in narrower bands than in other parts of the state to reduce competition with the vines for soil water and nutrients.

\section{Economics of grape production}

The economic aspects of wine grape production add another layer of complexity to selecting floor management strategies. This includes evaluating: 
(1) the cost and ease of implementing a practice, (2) the resulting weed population dynamics and their effect on crop yields and quality and (3) the level of risk or uncertainty associated with a technique, especially if it is a new or unknown technology (Bosch and Pease 2000). Growers use herbicides to manage risk because they reduce variability in management costs and yield, and therefore income, even though herbicide use may result in added costs in some situations (Olson and Eidman 1992). When multiple options for weed control exist, growers often consider trade-offs, or conflicting objectives that include direct financial costs and benefits along with indirect environmental and social costs and benefits, such as soil erosion and water quality (Wiles 2004).

This article examines how three weed management and three cover crop systems affect the costs of weed control in Central Coast wine grape production.

\section{Management practices}

Research site. The research was initiated in fall 2000, in a drip-irrigated vineyard near Greenfield in Monterey County. Greenfield has a Mediterranean climate, with annual rainfall ranging from 4 to 8 inches. The vineyard was established in 1996 with Vitis vinifera L. cv. Chardonnay on Teleki 5C (V. berlandieri Planch. $\times$ V. riparia Michx.) rootstock. Vine spacing was 8 feet between rows and 6 feet within rows. The soil was elder loam with gravelly substratum.

Experimental design. The in-row weed control treatments were:

(1) cultivation, (2) post-emergence weed control only (glyphosate at $2.0 \%$ plus oxyfluorfen at $1.0 \%$ ) and (3) preemergence and post-emergence weed control (simazine at 1.8 pounds active ingredient per acre plus oxyfluorfen at 1.0 pound active ingredient per acre; and glyphosate at $2.0 \%$ plus oxyfluorfen at $1.0 \%$, respectively). Cultivations and herbicide applications were timed in accordance with grower practices and label rates. Cultivations were performed as needed during the growing season (March through October) using a Radius Weeder cultivator (Clemens and Company, Wittlich, Germany). Cultivation consisted of a metal knife held perpendicular to the direction of
TABLE 1. Number of annual floor management operations and average costs, 2002-2005

\begin{tabular}{|c|c|c|c|c|c|c|c|}
\hline Practice/treatments & $\begin{array}{l}\text { Radius } \\
\text { Weeder }\end{array}$ & Herbicide & Plant cover & Disk & $\begin{array}{l}\text { Hand- } \\
\text { weed }\end{array}$ & $\begin{array}{l}\text { Side } \\
\text { disk }\end{array}$ & Mow \\
\hline \multicolumn{8}{|l|}{ Cultivation } \\
\hline Bare ground & $5-8^{*}$ & $-\dagger$ & - & $2-5$ & $1-2$ & $0-2$ & - \\
\hline 'Merced' rye & $5-8$ & - & 1 & - & $1-2$ & $0-2$ & $2-3$ \\
\hline 'Trios 102 ' triticale & $5-8$ & - & 1 & - & $1-2$ & $0-2$ & $2-3$ \\
\hline Average number/year $¥$ & 6.5 & - & 1 & 3.5 & 1.5 & 1 & 2.5 \\
\hline Average cost/operation (\$)§ & 8 & - & 33 & 6 & 96 & 6 & 7 \\
\hline Average cost/year $(\$) \emptyset$ & 52 & - & 33 & 21 & 144 & 6 & 18 \\
\hline \multicolumn{8}{|l|}{ Pre-emergence } \\
\hline Bare ground & - & $2-4$ & - & $2-5$ & - & - & - \\
\hline 'Merced' rye & - & $2-4$ & 1 & - & - & - & $2-3$ \\
\hline 'Trios 102 ' triticale & - & $2-4$ & 1 & - & - & - & $2-3$ \\
\hline Average number/year & - & 3 & 1 & 3.5 & & & 2.5 \\
\hline Average cost/operation (\$) & - & 38 & 33 & 6 & - & - & 7 \\
\hline Average cost/year $(\$)$ & 一 & 113 & 33 & 21 & - & 一 & 18 \\
\hline \multicolumn{8}{|l|}{ Post-emergence } \\
\hline Bare ground & - & $4-5$ & - & $2-5$ & - & - & - \\
\hline 'Merced' rye & - & $4-5$ & 1 & - & - & - & $2-3$ \\
\hline 'Trios 102 ' triticale & - & $4-5$ & 1 & - & - & - & $2-3$ \\
\hline Average number/year & - & 4.5 & 1 & 3.5 & - & - & 2.5 \\
\hline Average cost/operation (\$) & - & 22 & 33 & 6 & - & - & 7 \\
\hline Average cost/year (\$) & 一 & 100 & 33 & 21 & - & - & 18 \\
\hline $\begin{array}{l}\text { * Range for low and high number } \\
\dagger \text { Operation not used. } \\
\text { ‡ Average number of operations } p \\
\S \text { Cash costs rounded to nearest do } \\
\text { ๆ Based on number of operations }\end{array}$ & $\begin{array}{l}\text { annual oper } \\
\text { year. } \\
\text { ir. } \\
\text { d cumulative }\end{array}$ & h costs. & & & & & \\
\hline
\end{tabular}

the tractor movement, and inserted slightly below the soil surface to sever weed shoots from their roots. Preemergence herbicides were applied with a standard spray rig in fall or winter. Post-emergence herbicides were applied in spring, summer or fall as needed with a Patchen Weedseeker lightactivated sprayer (NTech Industries, Ukiah, Calif.); spray volume varied on a per-acre basis depending on weed cover.

Row-middle cover crop treatments were: (1) no cover crop (bare ground), (2) 'Merced' rye (Secale cereale L.) and (3) 'Trios 102' triticale $(\times$ Triticolsecale Wittm. Ex A. Camus). Cover crops were planted with a vineyard seed drill in the 32-inch centers of the 8-foot-wide rows just before the start of the rainy season in November of each year, from 2000 to 2005. Cover crops were mowed in spring to provide frost protection for the vines, and senesced in summer. Prior to planting cover crops each November, row middles were disked to incorporate the previous year's cover crop and stubble, and to prepare the seedbed. Bare-ground middles were kept free of weeds by periodic disking during the year (table 1).

Weed control (in-row main plot) and cover crop (row-middle subplot) treatments were arranged in a threeby-three split-block design with three replicate blocks covering a total of 23 vineyard rows, or 7 acres. Each block contained six vine rows and six adjacent middles. Weed control treatments were applied along the entire length of each vine row, which each had roughly 300 grapevines. Cover crop treatments were established along one-third of each middle and were continuous across the main plot treatments in each block. Each replicate main plot-bysubplot treatment combination included roughly 100 grapevines. Weed control data was collected under the vine rows (main plots) four to five times from spring through fall. Percentage vegetative cover and plant diversity were estimated using a line-intercept technique. Plant species intersecting points at 12 -inch intervals along a 100 -foot

\section{The post-emergence treatment achieved adequate weed control without the high-risk herbicide simazine.}




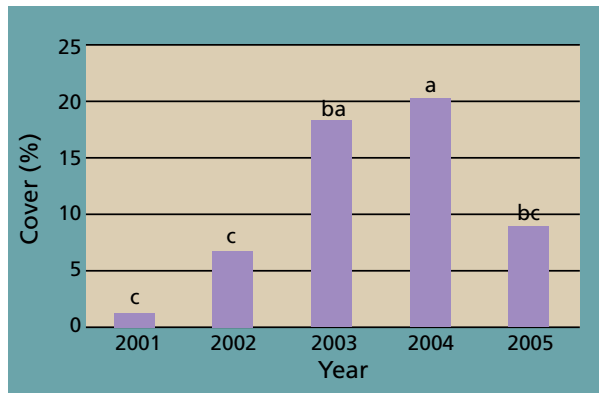

Fig. 1. Mean percentage cover of common purslane by year in the vine row in summer and fall weed evaluations. Bars with the same letter are not significantly different (Fisher's protected LSD test, $\alpha=0.05$ ).

transect were recorded in each plot, or in $18 \%$ of each plot.

Statistics. Yield data and quality were analyzed using ANOVA with mean separation by Duncan's multiple range test. Multiple year analyses were performed by utilizing a split-plot design, with weed control as the main plots and cover crops as subplots. Analysis of variance was used to make across-treatment comparisons for the cover of key weeds.

Economics. Partial budget analyses were performed using Budget Planner Software for the four growing seasons from 2002 to 2005 for each of nine vineyard floor management practice treatments. Data was collected by main plot and subplot, transformed and reported on a per-acre basis for the timing of each operation, equipment type and use (including fuel, lubrication and repairs), material inputs (herbicides and seed), labor hours (machine and field) and interest on operating capital. Data was entered into Budget Planner, which generated tables estimating annual cash costs per acre for each treatment's operations and inputs. We also calculated the average cost per operation and per year, and annual and cumulative cash costs per acre by treatment.

\section{Weed control}

Because the grower had used the same weed control strategy since establishing the vineyard 4 years before our experiment began, the initial weed population was assumed to be uniform across the experimental site. However, over the course of the 5-year trial, the three weed control strategies developed distinct weed communities. In each case, weeds that were less susceptible

\begin{tabular}{|c|c|c|c|}
\hline \multicolumn{4}{|c|}{$\begin{array}{l}\text { TABLE 2. Mean percentage cover of three selected weeds } \\
\text { in each weed control treatment, summer and fall } 2001-2005^{*}\end{array}$} \\
\hline Weed control treatments & Common purslane & Horseweed & Yellow nutsedge \\
\hline Cultivation & $11.5 a$ & $0.2 a$ & $4.3 a$ \\
\hline Pre-emergence & $0.7 \mathrm{~b}$ & $3.2 a$ & $7.3 a$ \\
\hline Post-emergence & $0.1 \mathrm{~b}$ & $4.0 \mathrm{a}$ & $4.9 a$ \\
\hline
\end{tabular}

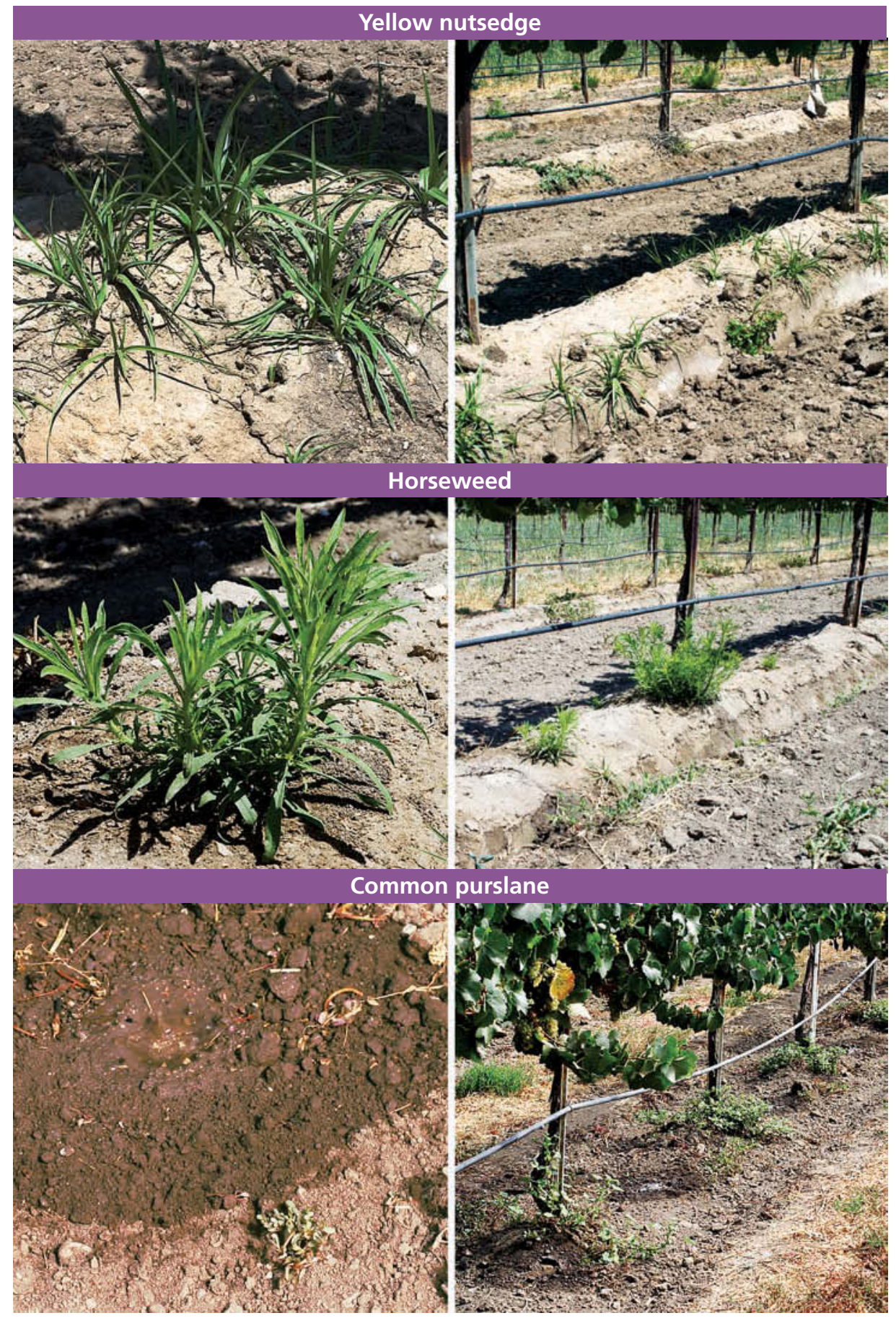

To assess the effectiveness of various vineyard floor management strategies, the authors compared pre- and post-emergence herbicide treatments with cultivation in the rows, and several different cover crops in the middle. The primary weeds in the Monterey County vineyard were yellow nutsedge, horseweed and common purslane. 
to that particular weed control strategy increased, most notably common purslane (Portulaca oleracea), horseweed (Conyza canadensis) and yellow nutsedge (Cyperus esculentus).

Purslane. The cover of common purslane was significantly greater in the cultivation treatment than the post-emergence and pre-emergence treatments (table 2). In the cultivation treatment, this weed increased dramatically during the first 4 years of the trial (fig. 1). Purslane was likely able to produce large amounts of seed since it can set seed in as little as 3 weeks, and the weeds were only cultivated roughly once a month (Haar and Fennimore 2003). During the fourth and fifth years of the trial, increased field labor for hand-weeding was required to bring this weed under control and minimize its potential to compete with grapevines for water and nutrients.

Horseweed. The overall percentage cover of horseweed was not significantly different in any treatment during the 5 years of this trial (table 2). Both cultivation and pre-emergence applications of simazine and oxyfluorfen provided good control of this weed throughout the trial. However, by the second growing season, horseweed populations had increased in the post-emergence treatment (data not shown) due to inadequate control with glyphosate and oxyfluorfen. To bring this weed under control in the postemergence treatment, it was necessary to include an application of glufosinate (at 3\% v/v) in early summer 2002, and in late spring or early summer in all subsequent years.

Yellow nutsedge. The most troublesome weed in the pre-emergence treatment was yellow nutsedge, which was not controlled at all by the preemergence application of simazine and oxyfluorfen. Additional summer herbicide applications were used to manage this weed, which resulted in higher overall costs when compared to the post-emergence treatments. Because additional herbicide applications were made, the percentage cover of yellow nutsedge over the 5 years of the trial did not significantly differ from the other weed control treatments (table 2).

\section{Crop growth, yield and quality}

The weed control treatments that we studied had no effect on vine growth. While cover crop treatments also had no significant effect on vine growth overall, the 'Trios 102' triticale treatment significantly reduced pruning weights in 2001 and 2005. Pruning weights are a measurement of seasonal growth. The lowered pruning weights that we found may be due to the fact that the 'Trios 102' triticale grows later and so uses more soil water than the rye.

No differences in crop yields or fruit composition were measured from 2000 to 2005 that could be attributed to the weed control treatments. Cover crop treatments, when averaged over the 5 years, also had no significant effect on yield or fruit composition, although in 2001 and 2004 there was a reduction in berry size with the triticale treatment.

Cover crops may compete with grapevines for water and nutrients, and this competition may be beneficial or detrimental to vine productivity and fruit quality depending on the amount of soil moisture available during the growing season. In this study, it appears that irrigation management practices were able to overcome the impact of water use by the cover crop, and fruit production losses were avoided. Higher water costs may be associated with this result, however, and irrigation practices were not part of the economic analysis for this experiment.

\section{Economic impacts}

The effectiveness of in-row weed control or lack thereof affected the economics of each strategy. Costs varied by year in response to differing levels of weed pressure and the timing of weed control practices.
Annual cash costs. The three weed control treatments had similar annual cash costs per acre in the second and third years of the trial (fig. 2A). However, in the fourth and fifth years, costs for the cultivation treatment dramatically increased by $\$ 160$ and $\$ 210$ per acre. This result is explained by the steady increase in percentage cover of common purslane, which peaked in 2004, and the concomitant need for supplemental labor to hand-weed around the vines (figs. 1 and 2A).

In general, the post-emergence treatment was the least costly of the three weed control treatments. The exception was in the fifth year of the study, when the cost of the pre-emergence treatment was slightly lower (fig. 2A). This is because by the 2005 growing season, persistent horseweed populations presented particular control challenges, and resulted in the need for higher application rates of the more costly herbicide glufosinate.

Cumulative cash costs. The cultivation treatment had by far the highest

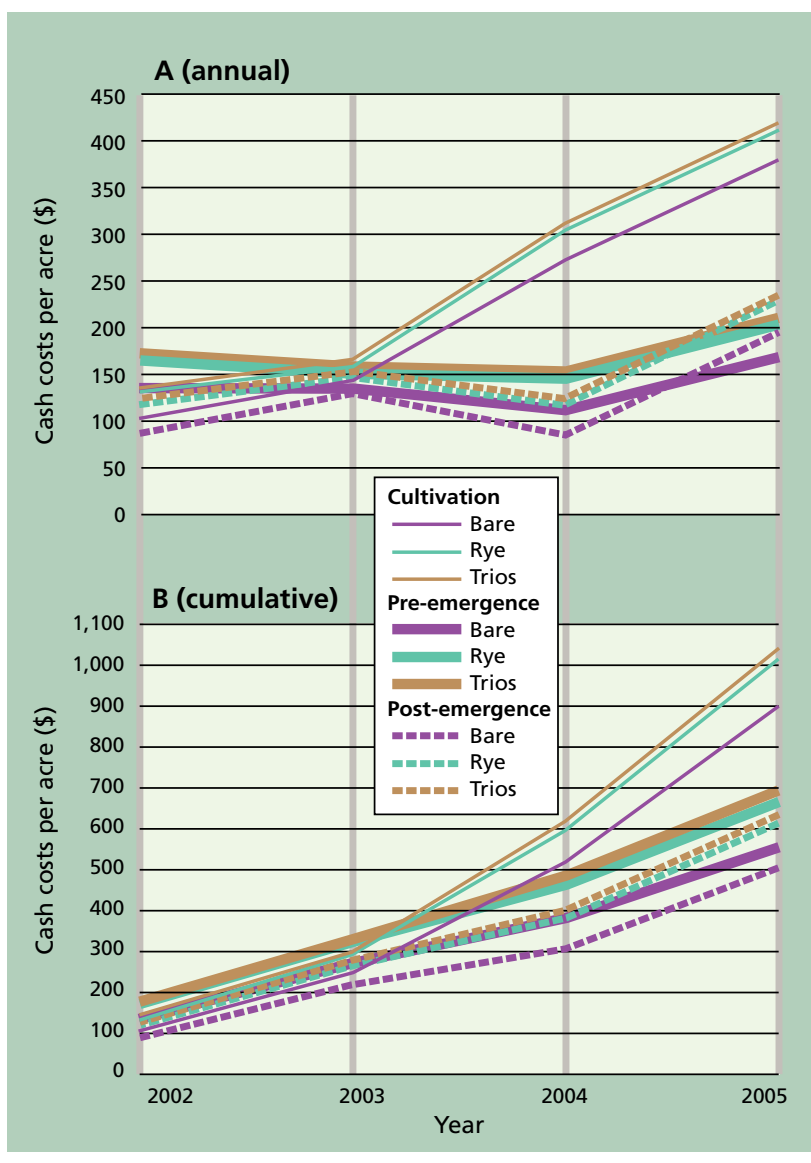

Fig. 2. (A) Annual and (B) cumulative cash costs per acre, by treatment. 

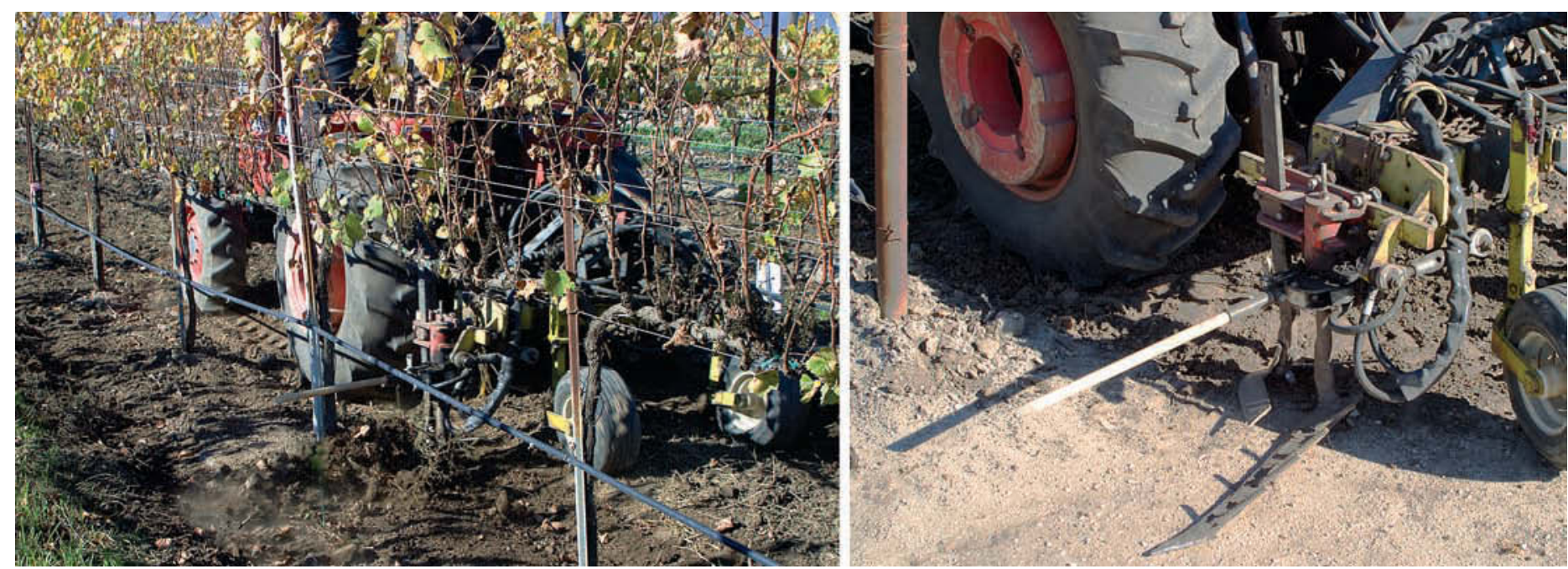

There were no differences in vine growth, crop yields or fruit composition among all the weed control treatments in the 5-year study, demonstrating that vineyard floors can be managed effectively without high-risk herbicides. For the cultivation treatment, above, the Radius Weeder inserts a knife into the soil to sever weed shoots from their roots.

cumulative cash costs, ranging from $\$ 899$ to $\$ 1,032$ per acre over the 4 -year study period (fig. 2B). The preemergence treatment had the next highest cumulative cash costs, ranging from $\$ 555$ to $\$ 690$ per acre. The postemergence treatment was least expensive, at $\$ 498$ to $\$ 633$ per acre.

In total, the post-emergence treatments generally maintained good weed control and used smaller amounts of chemicals than the preemergence treatment. In addition, the post-emergence treatment achieved adequate weed control without the high-risk herbicide simazine used in the pre-emergence treatment.

Cover crop costs. Annual costs for preparing the ground and planting row-middle cover crops averaged $\$ 33$ per acre per year in this trial (table 1). In years with low weed densities, cover crop costs ranged from between $20 \%$ and $30 \%$ of total floor-management costs; the cost range was lower in years with higher weed densities. The cost of planting and maintaining a cover crop in vineyards does not appear to dampen grower interest. In this production system, the cost of a cover crop may not be an annual expense because growers often manage cover crops to set seed, thus reducing the need to reseed each year.

\section{Choosing effective strategies}

This production, weed control and economic information can assist grow- ers in selecting practices and strategies for vineyard floor management. Weed control and cover crops have direct short-term financial costs and production implications; they have also been shown to have indirect and longer-term benefits for crop productivity, soil management, water quality and economic profitability. Affiliated research has shown beneficial impacts on nutrient cycling and soil microbiology (Baumgartner et al. 2005; Bettiga et al. 2006). This study has shown that weed control strategies without the inclusion of high-risk herbicides can be used effectively and economically to manage vineyard floors.

L. Tourte, R. Smith and L. Bettiga are Farm Advisors, UC Cooperative Extension (UCCE), Santa Cruz, Monterey and San Benito counties; T. Bensen is former Staff Research Associate, UCCE Monterey County; and J. Smith and D. Salm are growers and managers, Valley Farm Management, Soledad, Calif.

The Viticulture Consortium Program and the California Department of Pesticide Regulation (DPR) Reduced Risk Pest Management Grant Program funded this research. Thank you to Dave Miltz, Pat Headley and Adelia Barber, Research Assistants, UCCE Monterey County, for their contributions and assistance. Thanks also to Steve Fennimore, Extension Specialist, UC Davis Department of Plant Sciences, for his editing advice, and Karen Klonsky, Extension Specialist, UC Davis Department of Agricultural and Resource Economics, for her suggestions and assistance with the tables and graphs.

\section{References}

Baumgartner K, Smith R, Bettiga L. 2005. Weed control practices and cover crop management affect mycorrhizal colonization of grapevine roots and arbuscular mycorrhizal fungal spore populations in a California vineyard. Mycorrhiza 15:111-9.

Bettiga L, Smith R, Cahn M, Tourte L. 2006. Evaluation of the long-term impact of vineyard floor management practices on crop production and quality, weed control, soil and water parameters, and the economics of wine grape production. Viticulture Consortium Final Research Report. UCCE Monterey County. 44 p.

Bosch DJ, Pease JW. 2000. Economic risk and water quality protection in agriculture. Rev Agri Econ 22(2):438-63

Christensen P. 1971. Modified sod cover cropping in vineyards. Blue Anchor 48(3):20-2.

Costello MJ, Daane KM. 1997. Cover crops affect vine growth and vineyard microclimate. Grape Grower 29(8):22-5.

Elmore CL, Roncoroni R, Wade L, Verdegaal P. 1997. Mulch plus herbicides effectively control vineyard weeds. Cal Ag 51(2):14-8

Gaffney FB, van der Grinten M. 1991. Permanent cover crop for vineyards. In: Hargrove WL (ed.). Cover Crops for Clean Water. Soil and Water Conservation Society, Ankeny, IA. p 32.

Haar MJ, Fennimore SA. 2003. Evaluation of integrated practices for common purslane (Portulaca oleracea) management in lettuce. Weed Tech 17:229-33.

Hembree KJ, Ingels CA, Lanini WT. 2006. Weed management. UC IPM Pest Management Guidelines. www.ipm.ucdavis.edu/PMG/r302700111.html.

Hirschfelt D, Peacock W, Christensen P, Bianchi M 1993. Vineyard floor management, nitrogen uptake. Grape Grower 25(8):18-20

Ingels CA, Bugg RL, McGourty GT, Christensen LP (eds.). 1998. Cover Cropping in Vineyards: A Grower's Handbook. ANR Pub 3338. 162 p.

Lanini T, Bendixen W. 1992. Characteristics of important vineyard weeds. In: Flaherty DL, Christensen LP, Lanini WT, et al. (eds.). Grape Pest Management (2nd ed.). ANR Pub 3343. 412 p

Olson KD, Eidman VR. 1992. A farmer's choice of weed control method and the impacts of policy and risk Rev Agri Econ 14(1):125-37.

Wiles LJ. 2004. Economics of weed management: Principles and practices. Weed Tech 18:1403-7. 